\title{
Fast and Non-Destructive Determination of N, P, and K in Sorghum, Oat, and Corn Residue Using Near-Infrared Spectroscopy
}

\author{
A. Savi ${ }^{1}$, L. M. de Aguiar ${ }^{1}$, L. M. S. Tonial ${ }^{1}$, C. B. B. Lafay $^{1}$, T. S. Assmann ${ }^{1} \&$ M. A. de Bortolli ${ }^{1}$ \\ ${ }^{1}$ Federal Technological University of Paraná, Pato Branco, Paraná, Brazil \\ Correspondence: Larissa Macedo dos Santos Tonial, Departamento Acadêmico de Química, Universidade \\ Tecnológica Federal do Paraná, Câmpus Pato Branco, Via do Conhecimento Km 1, 85503-390 Pato Branco, PR, \\ Brazil. Tel: 55-463-220-2666. E-mail: larissasantos@utfpr.edu.br
}

Received: February 9, 2019

doi:10.5539/jas.v11n13p304
Accepted: June 2, 2019 Online Published: August 15, 2019

URL: https://doi.org/10.5539/jas.v11n13p304

\begin{abstract}
A fast and non-destructive method is reported to nitrogen, phosphorus and potassium quantification in sorghum, oat, and maize residues. The reflectance spectra of 261 litter plant samples using near-infrared spectroscopy were obtained with integrating sphere and sampling rotator. Second derivative spectra and Partial Least Squares were used to develop calibration and validation models. The cross-validation (leave-one-out) technique was used to evaluate the performance of the calibration and validation models, based on analytical parameters, root-mean-square error of estimation, determination coefficient, number of latent variables, residual prediction deviation, root-mean-square error of cross-validation. It was concluded that near-infrared spectroscopy and chemometric tools are a fast and non-destructive alternative to determine nitrogen and phosphorus content in sorghum, oat, and maize residues using calibration and validation models developed according to values obtained from traditional chemical methods. For potassium content, the results indicate the low quality (imprecision) of the calibration and validation models.
\end{abstract}

Keywords: analytical applications, calibration model, chemometric tools, NIR, validation model

\section{Introduction}

After harvesting, large amounts of residue plants accumulate above the soil. In no-till systems, these residues decompose and release an important quantity of nutrients, mainly nitrogen $(\mathrm{N})$, phosphorus $(\mathrm{P})$, and potassium (K), that will be absorbed by the crops cultivated after harvesting (Luce et al., 2016; Mbuthia et al., 2015; Jacob et al., 2010). Studies have characterized the chemicals found in these residues by litter-bag method.

The litter-bag method, in which the mass of litter incubated in mesh bags is measured over time, has become the standard method for estimating rates of residue decomposition (Moore et al., 2017; Assmann et al., 2015; Jacob et al., 2010). These studies are important because it provides information about the decomposition process of the plant, which influences the release of essential plant nutrients. However, due to the number of samples associated with the obstacles of traditional chemical methods, the farmers are not aware of the number of nutrients in the plant residue or how many of these nutrients can be available for use as fertilizer.

Thus, the growing interest in near-infrared (NIR) spectroscopy can be justified by the important advantages of this technique in relation to conventional analysis. The advantages of this technique are the following: (1) non-destructive method, (2) requires minimal or no sample preparation, (3) no reagents are required and it produces no waste, (4) multi-analytical technique, allows several simultaneous determinations (Santos et al., 2012; Santos et al., 2010; Blanco \& Villarroya, 2002). However, compared to the conventional analysis used in this field, the NIR spectroscopy has the disadvantages: (1) not providing molecular information (Mees et al., 2018), (2) requires the acquisition of the instrument that is relatively high, and (c) requires the construction of the calibration and validation models applied results obtained by conventional analysis.

Thus, despite the great number of nutrient analyses necessaries on nutrient release study and the difficulties related to the traditional chemical methods, the disadvantages of the NIR spectroscopy can be reason for all recent nutrients release researchers in Brazil did not use this technology (Assmann et al., 2014, 2015; Pitta et al., 2011). 
NIR spectroscopy has been explored as an analytical approach to analyze various agricultural matrices (Wang et al., 2015; Luce et al., 2014; Fujiwara \& Murakami, 2007; He et al., 2007). According to Lima et al. (2008), the results obtained using NIR spectroscopy for plant analysis show that the technique produces similar results to those obtained using the standard Kjeldahl procedure for $\mathrm{N}$ content, indicating that it can be used for routine analysis.

However, the interpretation of data obtained from NIR spectroscopy is not immediate and requires the use of multivariate analysis methods, such as Partial Least Squares (PLS). According to Balabin and Smirnov (2011), the use of chemometric tools is essential to obtain relevant information from NIR spectra, and the combination of both methodologies is necessary to develop calibration models.

In this study, we (1) use traditional methods for the chemical characterization $(\mathrm{N}, \mathrm{P}$, and $\mathrm{K}$ ) of sorghum, oat, and corn residues during the decomposition process; (2) propose a fast and non-destructive method to determine total $\mathrm{N}, \mathrm{P}$, and $\mathrm{K}$ levels in sorghum, black oat, and corn residues using NIR combined with chemometric tools; and (3) characterize the calibration and validation models using statistical parameters.

\section{Material and Method}

\subsection{Experimental Area}

The study was conducted in Abelardo Luz, in the state of Santa Catarina, southern Brazil $\left(26^{\circ} 31^{\prime} \mathrm{S}, 5^{\circ} 35^{\prime} \mathrm{W}, 850\right.$ $\mathrm{m}$ high), on a 20-ha field that has been in an integrated crop-livestock systems (ICLS) experiment using no-till since 2012. The experimental pasture phase began 7 November 2012 with sorghum planted no-till using the hybrid BMR-ADV 2800. The desiccation of sorghum pasture was on 22 April 2013 and on 25 April 2013 black oat (Avena strigosa) was planted no-till. After cattle were removed at the end of the pasture phase, plant residues were desiccated with $1.5 \mathrm{~L} \mathrm{ha}^{-1}$ of glyphosate. Maize hybrid 'Maximus' was sown on 10 October 2013 in a no-till system. The soil in the area is classified as Oxisol with clay texture. The climate type is Cfb, humid subtropical, according to Köppen's Classification.

$\mathrm{N}, \mathrm{P}$ and $\mathrm{K}$ release of sorghum, black oat and, corn residue were evaluated with litter-bags placed onto the surface soil of the succeeding sorghum, black oat, and corn crop.

Sorghum, black oat and corn residue were collected at the end of each crop. Stubble dry matter samples of $10 \mathrm{~g}$ were placed into 0.20 versus $0.20 \mathrm{~m}$ nylon-screen litter-bags with $0.002 \mathrm{~m}$ openings. Litter-bags were sealed and distributed to the experiment area at the soil surface to represent no-tillage conditions. Each litter-bag was placed 7 days after sowing each crop.

A total of six litter-bags of sorghum dry matter were placed in each experimental unit for retrieval at $15,35,55$, 75,100 and 135 days of incubation. In the case of black oat, eight litter-bags of dry matter were placed in each experimental unit for retrieval at 15, 27, 42, 62, 78, 96, 120 and 150 days of incubation and, seven litter-bags of corn dry matter were retrieved at 12, 28, 49, 84, 110, 136 and 182 days. Litter-bags contents were dried by a forced-air oven $\left(55^{\circ} \mathrm{C}\right)$.

Nutrients release were determined from differences in nutrient concentrations among incubation periods. Litter samples were ground to pass on $0.841 \mathrm{~mm}$ screen and then digested in sulfuric acid. The concentration of the digest was analyzed for total $\mathrm{N}$ with the Kjeldahl method, for $\mathrm{P}$ by photocolorimetry, for total $\mathrm{K}$ by flame photometry, and for $\mathrm{Ca}$ and $\mathrm{Mg}$ by atomic absorption spectrophotometry.

\subsection{NIR Spectra Collection}

NIR spectra of $20 \mathrm{~cm}^{3}$ of the sample were recorded in diffuse reflectance mode with the integrating sphere and sampling rotator using a Bruker MPA FT-NIR spectrometer (Bruker Optics Inc., Ettlingen, Germany). The system was operated using Spectral Acquisition and Processing Software (OPUS 7.2, Bruker Optics, Germany). Data were recorded from 4000 to $12000 \mathrm{~cm}^{-1}$ at a resolution of $32 \mathrm{~cm}^{-1}$, and each spectrum had an average of 64 scans per spectrum. Two replicate spectra were collected for each sample.

\subsection{Calibration and Validation Models}

The calibration and validation models were developed using software (OPUS 7.2, Bruker Optics, Germany). Spectral data from 261 samples of litter plant were studied in the construction of a PLS model, which proved effective in many quantitative applications and cross-validation method was applied in model validation with as several validation subsets as there were samples involved in the calibration model (leave-one-out method). The applied mathematical treatment was the second derivate. The potential of the calibration and validation models with cross-validation was evaluated using root-mean-square error of estimation (RMSEC), determination coefficient $\left(\mathrm{R}^{2}\right)$, number of latent variables $(\mathrm{LV})$, residual prediction deviation (RPD) and root-mean-square 
error of cross-validation (RMSECV). RMSEC is a measure of how well the model fits the calibration data in the cross-validation (Llario et al., 2006). RMSECV is a measure of the accuracy of the calibration model formed (Peirs et al., 2003). Good models should have lower RMSEC, RMSECV, and higher R ${ }^{2}$.

\section{Results and Discussion}

In Table 1 are presented the average, minimum, and maximum values and coefficient of variation for $\mathrm{N}, \mathrm{P}$, and $\mathrm{K}$ concentrations $\left(\mathrm{g} \mathrm{kg}^{-1}\right)$ in sorghum, black oat, and corn residues.

Table 1. Average, minimum, and maximum values and coefficient of variation for $\mathrm{N}, \mathrm{P}$, and $\mathrm{K}$ concentrations in sorghum, black oat, and corn residues in function of the initial incubation days and on the final date of incubation

\begin{tabular}{|c|c|c|c|c|c|c|}
\hline Parameter & Period incubation & Average & Minimum & Maximum & Release days & Coefficient of variation \\
\hline & & ---------- & --- $\mathrm{g} \mathrm{kg}^{-1}$ & ------------- & & \\
\hline \multicolumn{7}{|c|}{ Total $(n=36)$} \\
\hline \multirow[t]{2}{*}{$\mathrm{N}$} & Inicial & 15.39 & 1.70 & 37.40 & & 59.32 \\
\hline & Final & 15.86 & 3.40 & 28.90 & & 50.28 \\
\hline \multicolumn{7}{|c|}{ Sorghum $(n=10)$} \\
\hline \multirow[t]{2}{*}{$\mathrm{N}$} & Inicial & 15.30 & 11.90 & 20.40 & 0 & 18.35 \\
\hline & Final & 17.68 & 15.30 & 22.10 & 135 & 12.98 \\
\hline \multirow[t]{2}{*}{$\mathrm{P}$} & Inicial & 1.00 & 0.70 & 1.96 & 0 & 32.62 \\
\hline & Final & 0.65 & 0.58 & 0.72 & 135 & 6.81 \\
\hline \multirow[t]{2}{*}{$\mathrm{K}$} & Inicial & 57.29 & 49.00 & 68.50 & 0 & 10.19 \\
\hline & Final & 3.70 & 2.50 & 5.00 & 135 & 22.25 \\
\hline \multicolumn{7}{|c|}{ Black oat $(n=12)$} \\
\hline \multirow[t]{2}{*}{$\mathrm{N}$} & Inicial & 24.65 & 11.90 & 37.40 & 0 & 32.81 \\
\hline & Final & 22.10 & 5.10 & 28.90 & 150 & 30.96 \\
\hline \multirow[t]{2}{*}{$\mathrm{P}$} & Inicial & 1.15 & 0.76 & 2.80 & 0 & 46.85 \\
\hline & Final & 0.87 & 0.43 & 1.16 & 150 & 24.81 \\
\hline \multirow[t]{2}{*}{$\mathrm{K}$} & Inicial & 58.38 & 42.50 & 67.00 & 0 & 10.78 \\
\hline & Final & 15.54 & 3.50 & 49.50 & 150 & 101.54 \\
\hline \multicolumn{7}{|c|}{$\operatorname{Corn}(n=12)$} \\
\hline \multirow[t]{2}{*}{$\mathrm{N}$} & Inicial & 6.23 & 1.70 & 10.20 & 0 & 42.46 \\
\hline & Final & 6.23 & 3.40 & 8.50 & 182 & 33.40 \\
\hline \multirow[t]{2}{*}{$\mathrm{P}$} & Inicial & 0.35 & 0.25 & 0.41 & 0 & 12.24 \\
\hline & Final & 0.48 & 0.37 & 0.55 & 182 & 13.46 \\
\hline \multirow[t]{2}{*}{$\mathrm{K}$} & Inicial & 19.5 & 7.5 & 33.5 & 0 & 3.54 \\
\hline & Final & 5.22 & 3.00 & 7.00 & 182 & 27.13 \\
\hline
\end{tabular}

Note. The final date of incubation for sorghum, black oat and corn were 135, 150, and 182 days, respectively.

The highest average nutrient concentration was observed to $\mathrm{K}$ on black oat plant residue at 0-day incubation time (58.38 $\left.\mathrm{g} \mathrm{K} \mathrm{kg}^{-1}\right)$. Sorghum had the highest value of $\mathrm{K}$ and greatest content decay, from 68.50 to $2.50 \mathrm{~g} \mathrm{~K} \mathrm{~kg}^{-1}$ after 135 days of residue deposition in the soil (Table 1). This range can be attributed to the higher release speed of $\mathrm{K}$ from the residue. In a study of ryegrass (Tagliavini et al., 2007), found that $85 \%$ of initial $\mathrm{K}$ content was released during the first 4 weeks.

The fast release of $\mathrm{K}$ was observed in studies that evaluate decomposition and nutrient release from straw and animal residues. In the evaluation of poultry litter decomposition, the release of $\mathrm{K}$ was 84 and $91 \%$ for 15 and 30 days of incubation, respectively (Pitta et al., 2011). In the evaluation of vetch (Vicia vilosa) and radish (Raphanus sativus) residues, $\mathrm{K}$ release was $90 \%$ and $85 \%$, respectively, at the time of the first litter-bag sampling (15 days) (Giacomini et al., 2003). These data demonstrated a rapid release of $\mathrm{K}$ into the soil. The $\mathrm{K}$ cycle is simpler and faster than that of $\mathrm{N}$, mainly because $\mathrm{K}$ remains almost completely in the ionic form in plant tissues (Marschner, 1995). 
For all nutrients, the highest average values were observed in black oat, which is a C3 plant (Table 1). Values of $\mathrm{P}$ were the lowest among the species, and the highest average $\mathrm{P}$ value was also observed in black oat (1.15 $\mathrm{g} \mathrm{P}$ $\left.\mathrm{kg}^{-1}\right)$ (Table 1).

The $\mathrm{N}$ had intermediary values between $\mathrm{P}$ and $\mathrm{K}$ (Table 1) similar to rate release that also is intermediary to $\mathrm{K}$ and $\mathrm{P}$. $\mathrm{N}$ was immobilized during the decomposition process of sorghum residue. The average initial concentration of $\mathrm{N}$ on sorghum residue was $15.30 \mathrm{~g} \mathrm{~N} \mathrm{~kg}^{-1}$ and after 135 days of incubation, the nutrient average final concentration was $17.68 \mathrm{~g} \mathrm{~N} \mathrm{~kg}^{-1}$. When soil microorganisms have greater access to $\mathrm{N}$ due to $\mathrm{N}$ fertilization, the additional $\mathrm{N}$ is used to produce microbial biomass. This process can result in greater $\mathrm{N}$ immobilization and higher $\mathrm{N}$ content in litter under high $\mathrm{N}$ fertilization (Liu et al., 2011). Aita and Giacomini (2003) evaluated the decomposition of oat litter and found approximately $80 \%$ of $\mathrm{N}$ in the residues 15 days after field placement.

We collected NIR spectra of 261 litter plant samples in duplicate. Figure 1 shows the typical NIR spectra of sorghum, black oat, and corn residues. It is possible to observe good homogeneity in the set of spectra. Thus, owing to the overlap of bands, it is difficult to make quantitative predictions using direct interpretations from the NIR spectra, and multivariate analyses are needed to support the interpretation of results.
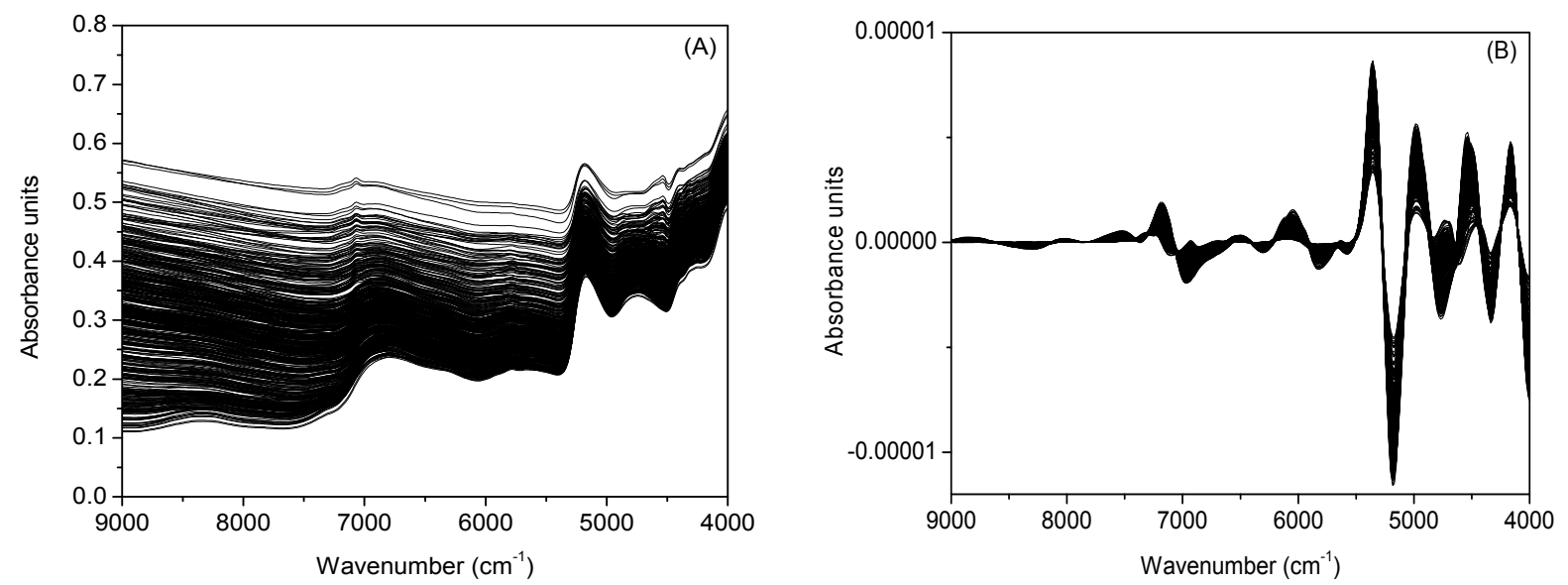

Figure 1. Near-infrared spectra of 261 samples from sorghum, black oat, and corn residues ranging from 12000 to $4000 \mathrm{~cm}^{-1}$ (A) before mathematical treatment and (B) after mathematical treatment

In general, the NIR spectra of sorghum, black oat, and corn residues have four groups of peaks in the regions: (1) $7169-6502 \mathrm{~cm}^{-1}$ (NH and $\mathrm{OH}$ first overtone bands), (2) 6022-5356 $\mathrm{cm}^{-1}$ (CH first overtone bands) and (3) $5356-4945$ and $4945-4516 \mathrm{~cm}^{-1}$ ( $\mathrm{NH}$ and $\mathrm{OH}$ combination bands) (Figure 1A).

The mathematical treatment employed in this work was the second derivative. The results show that the second derivative treatment was capable of suppressing the baseline variations. The second derivative spectra are highly overlapping (Figure 1B).

Table 2 shows the NIR calibration and validation results for the N, P, and K in sorghum, black oat, and corn residues samples.

Table 2. NIR calibration and validation results for N, P, and K in sorghum, black oat, and corn residues using the cross-validation method

\begin{tabular}{|c|c|c|c|c|c|c|c|c|}
\hline \multirow{3}{*}{ Parameter } & \multicolumn{8}{|c|}{ Cross-Validation } \\
\hline & \multicolumn{4}{|c|}{ Calibration } & \multicolumn{4}{|c|}{ Validation } \\
\hline & RMSEC* & $\mathrm{R}^{2}$ & LV & RPD & RMSECV* $^{*}$ & $\mathrm{R}^{2}$ & LV & RPD \\
\hline $\mathrm{N}$ & 0.13 & 0.97 & 8 & 5.55 & 0.14 & 0.96 & 8 & 5.14 \\
\hline $\mathrm{P}$ & 0.07 & 0.91 & 10 & 3.34 & 0.08 & 0.88 & 10 & 2.89 \\
\hline K & 2.3 & 0.95 & 9 & 4.57 & 2.61 & 0.94 & 9 & 3.97 \\
\hline
\end{tabular}

Note. ${ }^{*} \mathrm{~g} \mathrm{~kg}^{-1}$. 
RMSEC indicates the modeling error or calibration variance, thus the imprecision (quality) of the calibration model when tested internally. The RMSECV indicates the imprecision (quality) of the calibration model when tested internally. According to the results of RMSECV, the best model was for P $\left(\mathrm{RMSECV}=0.08 \mathrm{~g} \mathrm{~kg}^{-1}\right)$ (Table 2).

The $\mathrm{R}^{2}$ indicates the precision of the model. $\mathrm{R}^{2}$ approaches 1 as the predicted values approach the true values (Louw \& Theron, 2010). The calibration and validation models for $\mathrm{N}, \mathrm{P}$ and $\mathrm{K}$ indicate a good correlation between the NIR and traditional chemical methods (Table 2).

Thus, the best calibration and validation model is the one with the lowest RMSEC and the highest $\mathrm{R}^{2}$. The calibration results obtained show that the parameter with the greatest $\mathrm{R}^{2}$ does not have the greatest RMSEC (Table 2). Similar results were observed in the validation results.

NIR spectroscopy using the PLS, the second derivative with the cross-validation method using the spectral region 4000 to $12000 \mathrm{~cm}^{-1}$, could predict the $\mathrm{N}$ and $\mathrm{P}$ content in sorghum, black oat, and corn residues accurately up to an $\mathrm{R}^{2}$ value greater than 0.88 and a standard error value less than $0.14 \mathrm{~g} \mathrm{~kg}^{-1}$.

The measured versus predicted values from the $\mathrm{N}$ and $\mathrm{P}$ were correlated in a strong linear relation for each model Figure $2 \mathrm{a}$ and $2 \mathrm{~b}$, respectively. However, despite the high $\mathrm{R}^{2}$ value $(>0.94)$ (Figure $2 \mathrm{c}$ ), the high value of RMSEC $\left(2.3 \mathrm{~g} \mathrm{ka}^{-1}\right)$ and RMSECV $\left(2.61 \mathrm{~g} \mathrm{~kg}^{-1}\right)$ indicate that the application of NIR is insufficient for quantitative predictions. In the literature, opposite results showed the excellent prediction capacity of NIR to K determination in honey (Escuredo et al., 2015).
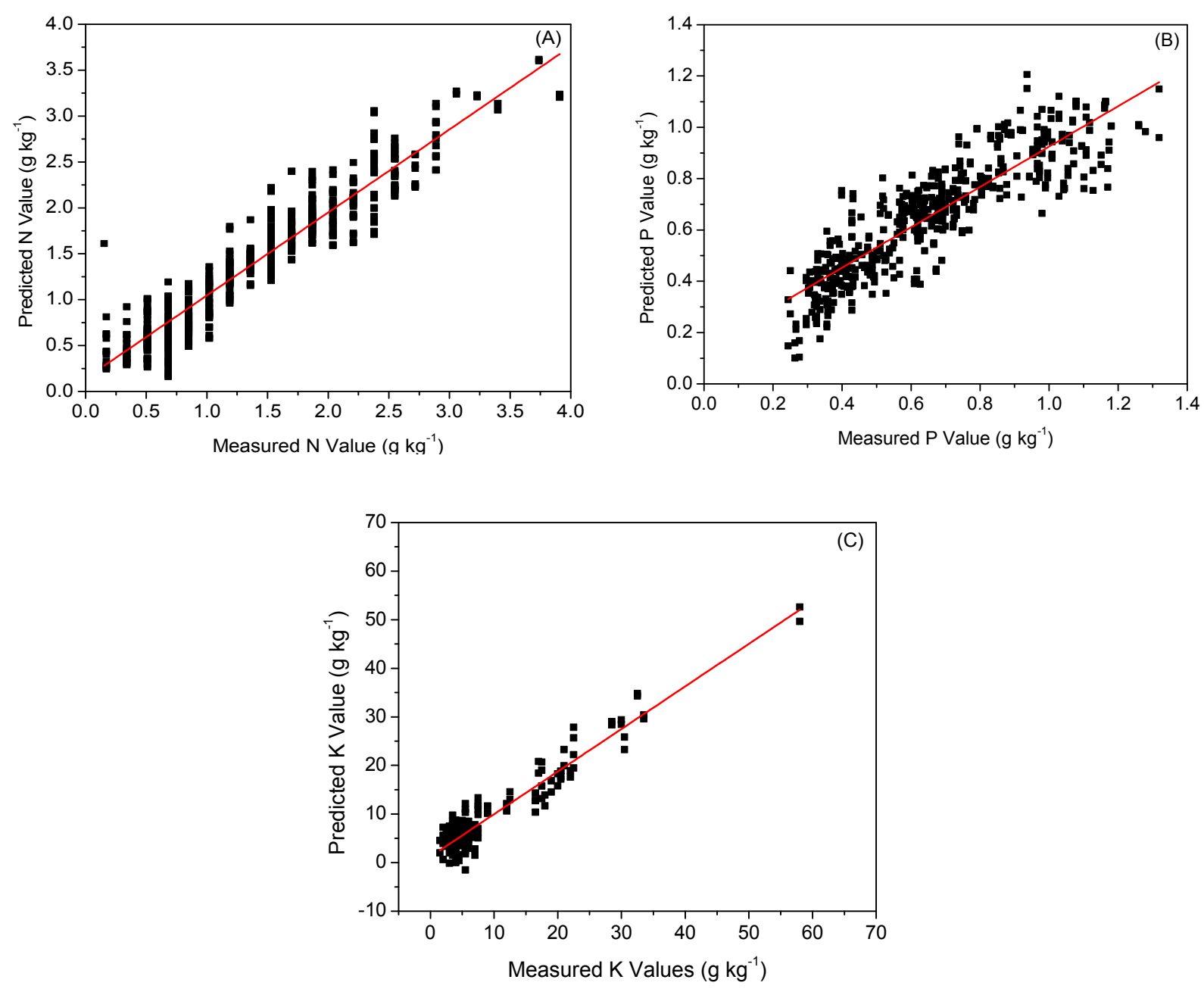

Figure 2. Relationship between measured laboratory values (x axis) of (A) N, (B) P and (C) K, and predicted values (y axis) by NIR of the calibration set 
The $\mathrm{N}$ and $\mathrm{P}$ models presented good prediction performances, which confirmed the results presented in Table 2 . These results indicate there was a strong linear relationship between the measured laboratory values and the values predicted by NIR within the calibration set (Figure 2).

The number of LV is the number of factors needed to explain the reference parameters from the spectral data. Generally, a lower number of LV is preferred over a high number of LV (>10) to avoid overfitting of the prediction equation (Stchur et al., 2002). The number of factors used for the calibration and validation models varied between 8 and 10 (Table 2).

The best calibration and validation model according to the results of the RMSEC and RMSECV was the model for P since it had the lowest RMSEC and RMSECV (Table 2).

The best calibration and validation model, according to the results of the number of $L V, R^{2}$, and RPD was the model obtained for $\mathrm{N}$ using cross-validation, as it had a high $\mathrm{R}^{2}$ and RPD, and a lower number of LV (Table 2).

These results demonstrate the good suitability of the developed calibration models for determining $\mathrm{N}$ and $\mathrm{P}$ in sorghum, black oat and corn residues, and the good agreement with the reference methods. Another indication of the good predictability of the developed NIR calibration models is given by the low RMSECV $\left(<0.14 \mathrm{~g} \mathrm{~kg} \mathrm{~g}^{-1}\right)$ and the high $\mathrm{R}^{2}(>0.88)$ and $\mathrm{RPD}(>2.89)$ (Table 2).

According to Hosseini et al. (2017) determination of $\mathrm{P}$ in soils is difficult due to the sensitivity of its measurement. According to Terhoeven-Urselmans et al. (2008) it might be linked to the fact that P can only be predicted indirectly due to the lack of absorbance in the NIR range. Malley et al. (2004) as certained that phosphates and other inorganic P compounds are hardly detectable by NIR spectroscopy due to the weak P-O dipole moment and the same happens with $\mathrm{K}$ compounds.

\section{Conclusions}

The NIR and chemometric tools proved to be a fast and non-destructive alternative for determining $\mathrm{N}$ and $\mathrm{P}$ content in sorghum, black oat, and corn residues. However, the results for K were not satisfactory.

The results show that calibration and validation models develop by NIR spectroscopy presented accurate capacity predictively for $\mathrm{N}$ and $\mathrm{P}$ content in plant residues. This conclusion is based for the high $\mathrm{R}^{2}$ values $(\geq$ 0.88 ) and low values for errors (RMSEC $\leq 0.13 \mathrm{~g} \mathrm{~kg}^{-1}$ and RMSECV $\leq 0.14 \mathrm{~g} \mathrm{~kg}^{-1}$ ) and RPD $(\leq 5.55)$. However, despite the good $\mathrm{R}^{2}$ values obtained for $\mathrm{K}$ calibration and validation models $(\geq 0.94)$, the high RMSEC and RMSECV values indicate the low quality (imprecision) of the calibration and validation models.

We conclude that the use of NIR spectroscopy coupled with chemometric tools can replace the slower chemical methods and reduce the consumption of reagents used in chemical analyses, and the consequent residues. Although this method does not require sample preparation, it requires equipment and a relatively large number of samples for calibration and validation. Further research can be extended to other plant residues and parameters.

\section{References}

Aita, C., \& Giacomini, S. J. (2003). Decomposição e liberação de nitrogênio de resíduos culturais de plantas de cobertura de solo solteiras e consorciadas. Rev. Bras. Ciênc. Solo, 27, 601-612. https://doi.org/10.1590/ S0100-06832003000400004

Assmann, J. M., Anghinoni, I., Martins, A. P., Costa, S. E. V. G. A., Kunrath, T. R., Bayer, C., ... Franzluebbers, A. J. (2015). Carbon and nitrogen cycling in an integrated soybean-beef cattle production system under different grazing intensities. Pesq. Agropec. Bras., 50, 967-978. https://doi.org/10.1590/ S0100-204X2015001000013

Assmann, T. S., De Bortolli, M. A., Assmann, A. L., Soares, A. B., Pitta, C. S. R., Franzluebbers, A. J., ... Assmann, J. M. (2014). Does cattle grazing of dual-purpose wheat accelerate the rate of stubble decomposition and nutrients released? Agric. Ecosyts. Environ., 190, 37-42. https://doi.org/10.1016/ j.agee.2014.01.011

Balabin, R. M., \& Smirnov, S. V. (2011). Variable selection in near-infrared spectroscopy: Benchmarking of feature selection methods on biodiesel data. Anal. Chim. Acta, 692, 63-72. https://doi.org/10.1016/ j.aca.2011.03.006

Blanco, M., \& Villarroya, I. (2002). NIR spectroscopy: A rapid-response analytical Tool. Trends Analit. Chem., 21, 240-250. https://doi.org/10.1016/S0165-9936(02)00404-1 
Escuredo, O., González-Martín, M. I., Rodríguez-Flores, M. S., \& Seijo, M. C. (2015). Near infrared spectroscopy applied to the rapid prediction of the floral origin and mineral content of honeys. Food Chem., 170, 47-54. https://doi.org/10.1016/j.foodchem.2014.08.061

Fujiwara, T., \& Murakami, K. (2007). Application of near infrared spectroscopy for estimating available nitrogen in poultry manure compost. J. Soil Sci. Plant Nutr., 53, 102-107. https://doi.org/10.1111/ j.1747-0765.2007.00109.x

Giacomini, S. J, Aita, C., Vendruscolo, E. R. O., Cubilia, M., Nicolosso, R. S., \& Fries, M. R. (2003). Matéria seca, relação $\mathrm{C} / \mathrm{N}$ e acúmulo de nitrogênio, fósforo e potássio em misturas de plantas de cobertura de solo. Rev. Bras. Ciênc. Solo, 27, 325-334. https://doi.org/10.1590/S0100-06832003000200012

He, Y., Huang, M., García, A., Hernández, A., \& Song, H. (2007). Prediction of soil macronutrients content using near-infrared spectroscopy. Comput. Electron. Agric., 58, 144-153. https://doi.org/10.1016/ j.compag.2007.03.011

Hosseini, M., Agereh, S. R., Khaledian, Y., Zoghalchali, H. J., Brevik, E. C., \& Naeini, S. A. R. M. (2017). Comparison of multiple statistical techniques to predict soil phosphorus. Appl. Soil Ecol., 114, 123-131. https://doi.org/10.1016/j.apsoil.2017.02.011

Jacob, M., Viedenz, K., \& Polle, A. (2010). Leaf litter decomposition in temperate deciduous forest stands with a decreasing fraction of beech (Fagus sylvatica). Oecol., 164, 1083-1094. https://doi.org/10.1007/ s00442-010-1699-9

Lima, K. M. G., Trevisan, M. G., Poppi, R. J., \& Andrade, J. C. (2008). Determinação não destrutiva do nitrogênio total em plantas por espectroscopia de reflectância difusa no infravermelho próximo. Quím. Nova, 31, 700-703. https://doi.org/10.1590/S0100-40422008000300039

Liu, K., Sollenberger, L. E., Silveira, M. L., Vendramini, J. M. B., \& Newman, Y. C. (2011). Grazing Intensity and Nitrogen Fertilization Affect Litter Responses in "Tifton 85" Bermudagrass Pastures: II. Decomposition and Nitrogen Mineralization. Agron. J., 103, 163-168. https://doi.org/10.2134/agronj2010.0320

Llario, R., Iñón, F. A., Garrigues, S., \& De La Guardia, M. (2006). Determination of quality parameters of beers by the use of attenuated total reflectance-Fourier transform infrared spectroscopy. Talanta, 69, 469-480. https://doi.org/10.1016/j.talanta.2005.10.016

Louw, E. D., \& Theron, K. I. (2010). Robust prediction models for quality parameters in Japanese plums (Prunus salicina L.) using NIR spectroscopy. Postharvest Biol. Technol., 58, 176-184. https://doi.org/ 10.1016/j.postharvbio.2010.07.001

Luce, M. S., Ziadi, N., Zebarth, B. J., Grant, C. A., Tremblay, G. F., \& Grerorich, E. G. (2014). Rapid determination of soil organic matter quality indicators using visible near infrared reflectance spectroscopy. Geoderma, 232, 449-458. https://doi.org/10.1016/j.geoderma.2014.05.023

Luce, M. St., Grant, C. A., Ziadi, N., Zebarth, B. J., O'donovan, J. T., Blackshaw, R. E., ... Mclaren, D. L. (2016). Preceding crops and nitrogen fertilization influence soil nitrogen cycling in no-till canola and wheat cropping systems. Field Crops Res., 191, 20-32. https://doi.org/10.1016/j.fcr.2016.02.014

Marschner, H. (1995). Mineral Nutrition of Higher Plants (2nd ed.). San Diego, USA: Academic Press. https://doi.org/10.1016/B978-012473542-2/50015-8

Malley, D. F., Martin, P. D., \& Ben-Dor, E. (2004). Application in analysis of soils. In C. Robert, J. Workman, \& J. B. Reeves (Eds.), Near-infrared Spectroscopy in Agriculture (pp. 729-784). Madison, WI: American Society of Agronomy, Crop Science Society of America and Soil Science Society of America.

Mbuthia, L. W., Acosta-Martínez, V., Debruyn, J., Schaeffer, S., Tyler, D., Odoi, E., ... Eash, N. E. A. L. (2015). Long term tillage, cover crop, and fertilization effects on microbial community structure, activity: Implications for soil quality. Soil Biol. Biochem., 89, 24-34. https://doi.org/10.1016/j.soilbio.2015.06.016

Mees, C., Souard, F., Delporte, C., Deconinck, E., Stoffelen, P., Stévigny, C., Kauffmann, J.-M., \& Braekeleer, K. (2018). Identification of coffee leaves using FT-NIR spectroscopy and SIMCA. Talanta, 177, 4-11. https://doi.org/10.1016/j.talanta.2017.09.056

Moore, T. R., Trofymow, J. A., Prescott, C. E., \& Titus, B. D. (2017). Can short-term litter-bag measurements predict long-term decomposition in northern forests? Plant Soil, 416, 419-426. https://doi.org/10.1007/ s11104-017-3228-7 
Peirs, A., Tirry, J., Verlinden, B., Darius, P., \& Nicolai, B. M. (2003). Effect of biological variability on the robustness of NIR models for soluble solids content of apples. Postharvest Biol. Technol., 28, $269-280$. https://doi.org/10.1016/S0925-5214(02)00196-5

Pitta, C. S. R., Soares, A. B., Assmann, T. S., Adami, P. F., Sartor, L. R., Migliorini, F., ... Assman, A. L. (2011). Dual-purpose wheat grain and animal production under different grazing periods. Pesq. Agrope. Bras., 46, 1385-1391. https://doi.org/10.1590/S0100-204X2011001000036

Santos, G. A., Pereira, A. B., \& Korndörfer, G. H. (2010). Use of analysis system by near infrared (NIR) for the analysis of organic matter and clay fraction in soils and leaf levels of silicon and nitrogen in sugar cane. Biosci. J., 26, 100-108.

Santos, G. A., Pereira, A. B., \& Korndörfer, G. H. (2012). System by near infrared (NIR) for analysis of nitrogen foliar. Biosci. J., 28, 83-90.

Stchur, P., Cleveland, D., Zhou, J., \& Michel, R. G. (2002). A review of recent applications of near infrared spectroscopy, and of the characteristics of a novel PbS CCD array-based near-infrared spectrometer. Appl. Spectrosc. Rev., 37, 383-428. https://doi.org/10.1081/ASR-120016293

Tagliavini, M., Tonon, G., Scandellari, F., Quiñones, A., Palmieri, S., Menarbin, G., ... Maisa, A. (2007). Nutrient recycling during the decomposition of apple leaves (Malus domestica) and mowed grasses in an orchard. Agric. Ecosyst. Environ., 118, 191-200. https://doi.org/10.1016/j.agee.2006.05.018

Terhoeven-Urselmans, T., Schmidt, H., Joergensen, R. G., \& Ludwing, B. (2008). Usefulness of near-infrared spectroscopy to determine biological and chemical soil properties: Importance of sample pre-treatment. Soil Biol. Biochem., 40, 1178-1188. https://doi.org/10.1016/j.soilbio.2007.12.011

Wang, Y., Huang, T., Liu, J., Lin, Z., Li, S., Wang, R., \& Ge, Y. (2015). Soil pH value, organic matter and macronutrients contents prediction using optical diffuse reflectance spectroscopy. Comput. Electron. Agr., 111, 69-77. https://doi.org/10.1016/j.compag.2014.11.019

\section{Copyrights}

Copyright for this article is retained by the author(s), with first publication rights granted to the journal.

This is an open-access article distributed under the terms and conditions of the Creative Commons Attribution license (http://creativecommons.org/licenses/by/4.0/). 